\title{
Cozinha Experimental Sobre Alívio de Sintomas para Acompanhantes de Pacientes em Quimioterapia de Hospital Público Oncológico.
}

\author{
Souza, Jane Lopes de; Souza, Micheline Tereza Pires de; Rosa, Vitor Modesto
}

Icesp — jane.souza@icesp.org.br

Introdução: Romper com a tradição clínica e epidemiológica do atendimento hospitalar proporcionou o desenvolvimento dos processos de saúde/doença/intervenção, pois torna o paciente, familiares e cuidadores sujeitos concretos desde o diagnóstico até as intervenções, possibilitando a participação ativa do usuário em contribuição do saber tecnológico. Objetivos: Capacitar acompanhante, de paciente em quimioterapia, ao manejo de sintomas, do tratamento, relacionados à alimentação para recuperação e manutenção do estado nutricional e possibilitar a manutenção do convívio familiar e social do paciente durante a alimentação. Métodos: Semanalmente às terças-feiras das $11 \mathrm{~h} 00$ às $12 \mathrm{~h} 00$ ocorre a atividade. na recepção da quimioterapia é exposto com antecedência um banner com informações sobre o número vagas, horário e tema da aula. Psicólogo e nutricionista do setor realizam as inscrições meia hora antes da aula e conduzem os inscritos até a cozinha experimental. a atividade consiste em aula sobre aspectos psicológicos da alimentação (psicologia) e aula sobre um sintoma do tratamento relacionado à alimentação e como manejá-lo (nutrição), e também, é realizada uma preparação coerente as orientações de manejo que é degustada pelos participantes. Todos recebem material de apoio (folder) contendo orientações nutricionais sobre o manejo do sintoma abordado e a receita preparada na aula. Além disso, os participantes preenchem ficha de avaliação da atividade para registrarem sua opinião e sugestões de novos temas. Resultados: em 2013 foram atendidos 216 acompanhantes em 41 cozinhas experimentais realizadas, que abordaram os temas: xerostomia, odinofagia, disgeusia, mucosite, náuseas e vômitos, diarreia e constipação intestinal. Todos os itens avaliados (tema da aula, palestrante, local da atividade, horário, duração, utilidade fora do hospital e recursos audiovisuais) pelos participantes receberam mais de $95 \%$ de excelente e bom. Conclusões: a aprovação da atividade reflete a importância do trabalho realizado, tornando possível a manutenção do paciente no convívio social da alimentação, passo importante na manutenção de uma boa qualidade de vida.

Souza, Jane Lopes de; Souza, Micheline Tereza Pires de; Rosa, Vitor Modesto. Cozinha Experimental Sobre Alívio de Sintomas para Acompanhantes de Pacientes em Quimioterapia de Hospital Público Oncológico.. In: Anais do Congresso Internacional de Humanidades \& Humanização em Saúde [= Blucher Medical Proceedings, num.2, vol.1]. São Paulo: Editora Blucher, 2014. ISSN 2357-7282

DOI 10.5151/medpro-cihhs-10709 